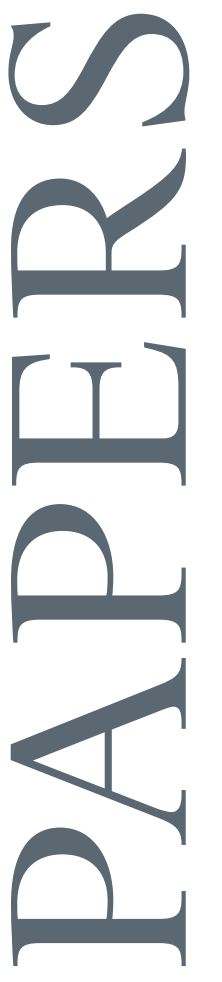

EAST-WEST CENTER WORKING PAPERS

\author{
Economics Series
}

No. 133, September 2013

Industrial Upgrading through Low-Cost and Fast InnovationTaiwan's Experience

Dieter Ernst

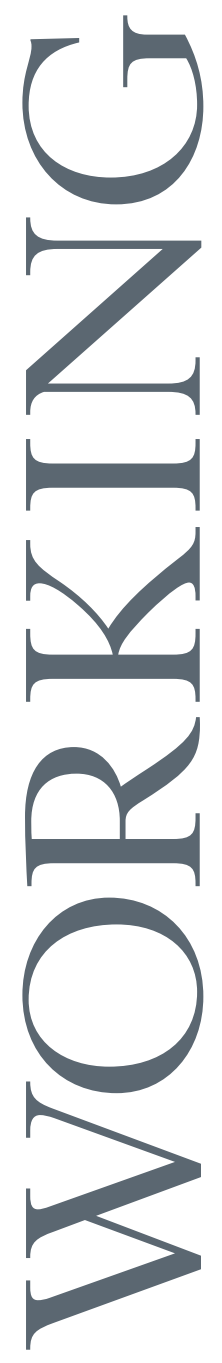

Je $\frac{\text { E A S T - W E S T C E N T E R }}{\text { COLlaboration • EXPertise - LeAdership }}$ 


\title{
Industrial Upgrading through Low-Cost and Fast Innovation- Taiwan's Experience
}

\author{
Dieter Ernst
}

East-West Center Working Papers is an unreviewed and unedited prepublication series reporting on research in progress. The views expressed are those of the author and not necessarily those of the Center. East-West Center Working Papers are circulated for comment and to inform interested colleagues about work in progress at the Center.

Working Papers are available online for free at EastWestCenter.org/ewcworkingpapers. To order print copies ( $\$ 3.00$ each plus shipping and handling), contact the Center's Publication Sales Office.

The East-West Center promotes better relations and understanding among the people and nations of the United States, Asia, and the Pacific through cooperative study, research, and dialogue. Established by the US Congress in 1960, the Center serves as a resource for information and analysis on critical issues of common concern, bringing people together to exchange views, build expertise, and develop policy options.

The Center's 21-acre Honolulu campus, adjacent to the University of Hawai'i at Mānoa, is located midway between Asia and the US mainland and features research, residential, and international conference facilities. The Center's Washington, DC, office focuses on preparing the United States for an era of growing Asia Pacific prominence.

The Center is an independent, public, nonprofit organization with funding from the US government, and additional support provided by private agencies, individuals, foundations, corporations, and governments in the region.

\section{EastWestCenter.org/publications}

Publication Sales Office| East-West Center 1601 East-West Road | Honolulu, Hawai'i 96848-1601

Tel: 808.944.7145 | Fax: 808.944.7376

EWCBooks@EastWestCenter.org
Dr. Dieter Ernst, East-West Center senior fellow, is an authority on global production networks and $\mathrm{R} \& \mathrm{D}$ internationalization in hightech industries and on industrial and innovation policies in the US, China, India, and other emerging economies, with a focus on standards and intellectual property rights. He serves as a scientific advisor to the US National Academies, governments, private companies, the World Bank, and other international organizations.

Publications include America's Voluntary Standards System-A "Best Practice" Model for Asian Innovation Policies (2013); Indigenous Innovation and Globalization: The Challenge for China's Standardization Strategy (2011) [now published in Chinese]; China's Innovation Policy Is a Wake-Up Call for America (2011); A New Geography of Knowledge in the Electronics Industry? Asia's Role in Global Innovation Networks (2009); Can Chinese IT Firms Develop Innovative Capabilities within Global Knowledge Networks? (2008); China's Emerging Industrial Economy-Insights from the IT Industry (with Barry Naughton) 2007; Innovation Offshoring-Asia's Emerging Role in Global Innovation Networks (2006); “Complexity and Internationalization of Innovation: Why is Chip Design Moving to Asia?," International Journal of Innovation Management (2005); International Production Networks in Asia: Rivalry or Riches? (2000); and Technological Capabilities and Export Success-Lessons from East Asia (1998).

This paper is a first draft of a book chapter in Ernst, D., forthcoming, Competing Approaches to Industrial Innovation-US, China, Taiwan, and India. An earlier draft was prepared as a background report for the 2012 US National Academies study The New Global Ecosystem in Advanced Computing. 


\title{
Industrial Upgrading through Low-Cost and Fast Innovation -
}

\author{
Taiwan's Experience ${ }^{1}$
}

by

\author{
Dieter Ernst, East-West Center
}

\begin{abstract}
This paper examines the forces that drive Taiwan's new strategy of "Upgrading through Low-Cost and Fast Innovation". The first section highlights characteristics of Taiwan's traditional "Global Factory" innovation model and examines the role of innovation policy in that model. Section 2 reviews fundamental weaknesses that define the requirements of Taiwan's new innovation strategy. Section 3 explores Taiwan's new strategy of "low-cost and fast innovation through domestic and global innovation networks". Finally, section 4 examines the role of government and key policies and initiatives in the IT industry.
\end{abstract}

\footnotetext{
${ }^{1}$ This paper is a first draft of a book chapter in Ernst, D., forthcoming, Competing Approaches to Industrial Innovation - US, China, Taiwan, and India. An earlier draft was prepared as a background report for the 2012 US National Academies study The New Global Ecosystem in Advanced Computing, http://www.nap.edu/catalog.php?record $\mathrm{id}=13472$. The analysis of Taiwan's innovation policy draws on Ernst, D. 2010, "Upgrading through Innovation in a Small Network Economy: Insights from Taiwan's IT industry", Economics of Innovation and New Technology, Vol.19, No.4: p.295-324; Science \& Technology Policy Research and Information Center, Yearbook of Science and Technology Taiwan ROC 2010, Taipei, http: // yearbook.stpi.org.tw; Ministry of Economic Affairs, 2011, 2011 White Paper on Taiwan Industrial Technology, Taipei, http://doit.moea.gov.tw/itech/eindex.asp?TYear=2011; Chen, Shin-Horng, 2010, Country Report Taiwan, prepared for European Commission, International Center for Economic Growth, Contract \# 150970-2008 F1SC-HU, October; Larsen, P.B. et al, 2011, "National Innovation Policy Profile Taiwan", in Cross-Sectoral Analysis of the Impact of International Industrial Policy on Key Enabling Technologies, Final Report, prepared for the European Commission, DG Enterprise \& Industry, March 28, pages 193- 200; Sha, K.H.C. et al, 2008, ÍTRI's Role in Developing the Access Network Industry in Taiwan, in H.S. Rowen, M.Gong Hancock and W. F. Miller, eds, Greater China's Quest for Innovation, The Walter H. Shorenstein Asia-Pacific Research Center; Chu, Hsin-Sen, 2007, "The Taiwanese Model: Cooperation and Growth", in Wessner, C.W., editor, Innovation Policies for the $21^{\text {st }}$ Century. A Report of a Symposium, The National Academies Press, Washington, D.C., pages 112-120; Chen, Tain-jy, 2004. "The Challenges of the Knowledge-Based Economy”, in: Chen, Tain-jy and Joseph S. Lee (eds), The New Knowledge Economy of Taiwan, Cheltenham: Edward Elgar; and Ernst, D., 2000, "What Permits David to Grow in the Shadow of Goliath? The Taiwanese Model in the Computer Industry", in: Borrus, M., D. Ernst and S. Haggard (eds.), International Production Networks in Asia. Rivalry or Riches?, London: Routledge. Additional sources include the CIA Fact book: Taiwan. 2011, https://www.cia.gov/library/publications/the-world-factbook/geos/tw.html; Tsai, T. and B.S. Cheng, eds, 2006, The Silicon Dragon. High-Tech Industry in Taiwan, Edward Elgar, Cheltenham, UK etc; and Addison, C., 2001, Silicon Shield. Taiwan's Protection against Chinese Attack, Fusion Press, Irving, Texas.
} 


\begin{abstract}
About the author
Dieter Ernst, East-West Center senior fellow, is an authority on global production networks and R\&D internationalization in high-tech industries and on industrial and innovation policies in the US, China, India and other emerging economies, with a focus on standards and intellectual property rights. Dr. Ernst served as a member of the US National Academies' Committee on Global Approaches to Advanced Computing; a senior advisor to the OECD, Paris; research director of the Berkeley Roundtable on the International Economy (BRIE) at the University of California at Berkeley; professor of international business at the Copenhagen Business School; and scientific advisor to governments, private companies and international institutions.

Relevant publications include America's Voluntary Standards System. A "Best Practice" model for Asian Innovation Policies (2013); Indigenous Innovation and Globalization: The Challenge for China's Standardization Strategy (2011) [now published in Chinese]; China's Innovation Policy Is a Wake-Up Call for America (2011); A New Geography of Knowledge in the Electronics Industry? Asia's Role in Global Innovation Networks (2009); "Innovation Offshoring-Root Causes of Asia's Rise and Policy Implications", in: Palacio, Juan J.(Ed.), 2007, Multinational Corporations and The Emerging Network Economy in the Pacific Rim, Co-published with the Pacific Trade and Development Conference (PAFTAD), London: Routledge; China's Emerging Industrial EconomyInsights from the IT Industry (with Barry Naughton), 2007; Innovation Offshoring-Asia's Emerging Role in Global Innovation Networks (2006): "Complexity and Internationalization of Innovation: Why is Chip Design Moving to Asia?," International Journal of Innovation Management, 2005; "Limits to Modularity - Reflections on Recent Developments in Chip Design," Industry and Innovation, 2005; "Global Production Networks, Knowledge Diffusion and Local Capability Formation", (with Linsu Kim), Research Policy, special issue in honor of Richard Nelson and Sydney Winter, 2002; International Production Networks in Asia: Rivalry or Riches? (2000).
\end{abstract}




\section{Introduction}

A defining characteristic of Taiwan's IT industry is its deep integration into diverse global corporate networks of production and innovation. Equally important, Taiwan's manufacturing R\&D is highly concentrated in the IT industry, accounting for $70 \%$ of Taiwan's manufacturing $R \& \mathrm{D}^{2}$.

While network integration has facilitated the catching-up of Taiwanese firms as fast-followers, it now has become a mixed blessing, unless appropriate policies are put in place to develop domestic capabilities for low-cost innovation both at the firm level and across the industry. As for R\&D in the IT industry, until recently its focus has been on incremental innovation. There is a growing recognition that Taiwanese firms now must increase $\mathrm{R} \& \mathrm{D}$ in order to avoid diminishing returns of network integration.

Taiwanese firms and policy-makers are still groping in the dark what precisely that strategy requires, for the time being content with adopting a pragmatic trial-and-error approach until they find something that works. Like in the EU, Taiwan's new innovation strategy is still "work in progress." However, some major building blocks of Taiwan's new innovation policy are gradually taking shape. In essence, that new approach combines market-led innovation and public policy coordination of multiple layers of private and public innovation stakeholders.

Due to its pragmatism and openness to new forms of public policy and privatepublic partnerships, Taiwan's innovation policy may in fact shed new light on the opportunities and challenges for strengthening America's innovation capabilities in advanced computing.

To understand what drives Taiwan's new strategy of "Upgrading through LowCost and Fast Innovation", the first section highlights characteristics of Taiwan's traditional "Global Factory" innovation model and examines the role of innovation policy in that model. Section 2 reviews fundamental weaknesses that define the requirements of Taiwan's new innovation strategy. Section 3 explores Taiwan's new strategy of "low-cost and fast innovation through domestic and global innovation networks". Finally, section 4 examines the role of government and key policies and initiatives in the IT industry.

\section{Taiwan's "Global factory" innovation model ${ }^{3}$ 1.1. Characteristics}

Less than half a century ago, Taiwan was poor and underdeveloped. Yet, by the turn of the century, this small, resource-poor island at the margin of the world economy had established itself as an important "global high tech factory" for PC-related products, handsets, wireless equipment, integrated circuits and flat panel displays. For global IT industry leaders, Taiwanese firms became preferred OEM (original equipment manufacturing) and ODM (original design manufacturing) suppliers ${ }^{4}$.

\footnotetext{
${ }^{2}$ Between 2001 and 2006, almost $90 \%$ of the R\&D investment of Taiwan's private sector was concentrated on two sectors, electronics components $(56 \%)$ and computers \& electronic and opto-electronic products (32\%). See http://eng.stat.gov.tw/ct.asp?xItem=6503\&CtNode $=2202 \& m p=5$

${ }^{3}$ This section draws heavily on Ernst, D. 2010, "Upgrading through Innovation in a Small Network Economy: Insights from Taiwan's IT industry", Economics of Innovation and New Technology, Vol.19, No.4: p.297-302

${ }^{4}$ An OEM contract refers to arrangements between a brand name company ( the customer) and the contractor ( the supplier), where the customer provides detailed technical blueprints and most of the components to allow the contractors to produce according to specifications. In ODM arrangements, the
} 
Taiwan's achievements in the IT industry would be impressive for any country they are even more impressive for a country that is about one-third the size of New York State. Like other small economies, Taiwan had to cope with a vicious circle of sizerelated disadvantages. With a population of about 21 million people, roughly half the size of South Korea, Taiwan lacked a large and sophisticated domestic market, specialized capabilities and support industries, and the science and technology infrastructure necessary for developing a broad set of electronics products.

The small domestic market places tight restrictions on the ability to function as a buffer against heavy fluctuations in international demand. It constrains the development of sophisticated "lead users" that could stimulate innovation, and it also limits the scope for technological spill-overs ${ }^{6}$. In addition, the limited size of the national knowledge and capital base restricts the choice of industries in which such small nations might successfully specialize.

Thus, Taiwan's IT industry had to rely heavily on international markets and access to foreign technology, tools and ideas. The key to Taiwan's success in this industry has been an early integration into diverse and constantly evolving network arrangements that include both formal corporate and informal knowledge networks.

Formal corporate production networks link Taiwanese firms to large global brand leaders (the customers), investors, technology suppliers and strategic partners through foreign direct investment (FDI) as well as through venture capital, private equity investment and contract-based alliances. Equally important are informal global knowledge networks that link Taiwan to more developed overseas innovation systems and knowledge communities, primarily in the US, through the international circulation of students and knowledge workers ${ }^{7}$ Finally, domestic inter-organizational linkages with large Taiwanese business groups complement these international linkages ${ }^{8}$ (Amsden and Chu, 2003; Ernst, 2001a).

A progressive integration into these diverse production, knowledge and innovation networks has enabled Taiwanese firms to combine the speed and flexibility of smaller firms with the advantages of scale and scope that normally only large firms can

contractor is responsible for design and most of the component procurement, with the brand name company retaining exclusive control over marketing.

${ }^{5}$ Von Hippel defines "lead users of a novel or enhanced product, process, or service" as those that "...face needs that will be general in the market place, but...(who) face them months or years before the bulk of that marketplace encounters them..." and who will "... benefit significantly by obtaining a solution to those needs." (Von Hippel, E., 1988. The Sources of Innovation, Oxford University Press, New York and Oxford: p.107)

${ }^{6}$ According to Zander and Kogut, large countries will benefit more from an investment in R\&D than smaller countries, where some of the spill-overs of R\&D are likely to benefit its trading partners. (Zander, U. and B. Kogut, 1995. "Knowledge and the speed of the transfer and imitation of organizational capabilities: An empirical test”, Organizational Science, 6, (1).

${ }^{7}$ Between 1987 and 2003, this small island has been the fifth largest nation of origin of international students in the U.S. (Guo, 2005: 142).

${ }^{8}$ Ernst, D., 2001, "Small Firms Competing in Globalized High Tech Industries: The Co-Evolution of Domestic and International Knowledge Linkages in Taiwan's Computer Industry", in: Guerrieri, P., S. Iammarino, and C. Pietrobelli (eds.), The Global Challenge to Industrial Districts. Small and MediumSized Enterprises in Italy and Taiwan, Aldershot: Edward Elgar. 
reap. Taiwanese firms have been able to tap into the world's leading markets, especially in the United States, compensating for the initially small size of their domestic market. In addition, network participation has multiplied conduits for knowledge transfers to Taiwanese IT firms, broadening their scope for learning and capability development. This, in turn, has created new opportunities, pressures, and incentives for Taiwanese network suppliers to upgrade their technological and management capabilities and the skill levels of workers.

\subsection{Public policy}

Public policy has played an important role in developing Taiwan's innovation capacity. As Taiwan's IT firms, almost without exception, have started out small and from very humble origins, they initially faced substantial entry barriers to network participation. Public policies and support institutions (like ITRI and Hsinchu Science Park) have played a critical role in overcoming the disadvantage of small size and limited resources.

A defining characteristic of Taiwan's innovation policy has been its attempt to include multiple stakeholders in the planning, promotion, implementation and evaluation of a national innovation strategy and its translation into sector-specific policies.

The process starts with the National Science and Technology Conference held every four years that brings together stakeholders from academia, industry, civil society and government to develop broad consensus strategy. Then, short- and mid-term S\&T policies are adjusted in multiple and increasingly specialized innovation dialogues organized by the Ministry of Economic Affairs and other government agencies, and the S\&T development vision and current status are regularly examined by the Science and Technology Advisory Group (STAG) of the Executive Yuan, and industry S\&T meetings. Highlighting the open nature of Taiwan's innovation policy, seven out of the 20 members of the powerful STAG are leading foreign scientists (three from the US, one from Canada, two from the EU, and one from Hong Kong) ${ }^{9}$. This openness to foreign strategic advice and knowledge sharing distinguishes Taiwan from Japan, Korea and China with their much more closed systems of innovation policy.

Over time, the focus of Taiwan's innovation policies has shifted to education, infrastructure and capability development, as Taiwan's network integration has moved up from very simple OEM arrangements to increasingly complex ODM arrangements that involve product development. To stay on the networks, Taiwanese firms had to recruit highly skilled and experienced knowledge workers, and they needed quick access to core technologies.

The Taiwanese approach to innovation policy has emphasized the provision of ample tax incentives to enable firms (most of them SMEs) to recruit top talent and to develop in-house technological capabilities. In addition, industrial support policies helped to disseminate market and industry intelligence and induced overseas Taiwanese engineers and managers to return home and/or to invest in Taiwan-based ventures. These

\footnotetext{
${ }^{9}$ See table 1-1-1-1 S\&T Advisors of the Executive Yuan, 2009, in Science \& Technology Policy Research and Information Center, Yearbook of Science and Technology Taiwan ROC 2010, Taipei, p. 101. Reflecting the dominance of the IT industry, seven STAG members have a background in IT, includingWilliam Spencer, the former chairman of SEMATECH.
} 
policies have enabled Taiwanese firms to accelerate learning, knowledge sharing and capability development.

\subsection{Achievements}

A defining characteristic of Taiwanese IT firms is that they were able to combine low-cost production and quick response to changes in markets and technology. Low-cost production was made possible by rigorous cost control management and the establishment of a low-cost supply base in China and Southeast Asia. Quick response relied on a flexible system of supplier networks characterized by temporary "spider web" arrangements that are assembled for the duration of a particular project, and then dissolved.

To expand their position as network suppliers, Taiwanese firms had to move beyond the provision of manufacturing services, and develop integrated service packages that include logistics and product development For instance, substantial improvements in supply chain management were implemented through extensive use of IT-enabled information systems and flexible adjustments of organizational structures.

Equally important, Taiwanese firms have made considerable progress in product development, especially in electronic design. Since the late 1980s, Taiwan's leading PC firms have established R\&D labs in Silicon Valley to gain early access to the product and technology road maps of the global industry leaders and to improve their product development capabilities. Already during the mid-1980s, Taiwan's semiconductor firms started to get involved in board-level and ASIC design ${ }^{10}$. This has given rise to a broad portfolio of design implementation capabilities, enabling Taiwanese semiconductor firms to compete on the speed, cost, flexibility and quality of providing these services ${ }^{11}$. Much of this progress was made possible by the establishment of a highly integrated domestic semiconductor industry value chain, coordinated by ITRI.

\section{Structural Weaknesses}

The downturn in the global electronics industry since late 2000 has exposed structural weaknesses of Taiwan's "global high tech factory" model. Intense price competition from new lower-cost competitors in China has reduced profit margins of Taiwanese firms. This limits funds available for R\&D and makes it difficult to sustain wage increases $^{12}$. Furthermore, relocation of production to Southeast Asia and China has reduced the job creation capacity of Taiwan's IT industry.

\subsection{Negative effects of network integration}

Taiwan's focus on the provision of OEM/ODM services has led to a combination of slow growth of value added, and a decline of value-added ratios and domestic linkages.

\footnotetext{
${ }^{10}$ Ernst, D. and O'Connor, D., 1992. Competing in the Electronics Industry. The Experience of Newly Industrialising Economies, Development Centre Studies, OECD, Paris, 303 pages ${ }^{11}$ Board-level design today covers very complex multi-layer boards. Combined with the experience in detailed product design and engineering that Taiwan firms have accumulated in the fabrication of ICs, board-level design has given rise to a broad portfolio of design implementation capabilities. Taiwanese firms have also moved well ahead in system specification and in the complexity of circuit and system design.

${ }^{12}$ Chen, Tain-jy, 2004. "The Challenges of the Knowledge-Based Economy", in: Chen, Tain-jy and Joseph S. Lee (eds), The New Knowledge Economy of Taiwan, Cheltenham: Edward Elgar.
} 
There are concerns that, as long as the country sticks to this industrial development model, the resultant reduction in learning and value creation could severely constrain the capacity of Taiwan firms to invest in "upgrading through low-cost innovation" strategies.

Taiwanese firms typically are under relentless pressure by global brand marketers to reduce cost and time-to-market for commodity-type products with low profit margins that are apt to penetrate mass markets. Taiwanese firms are thus stuck in a "commodity price trap", with low value-added and razor-thin profit margins that are insufficient to support investment in $\mathrm{R} \& \mathrm{D}$, intellectual property creation and branding.

Taiwan handset makers provide a telling example. To improve their profitability, they have all tried since around 2003 to increase their branded handset sales relative to their OEM/ODM business. Yet, with the possible exception of $\mathrm{HTC}^{13}$, practically all these attempts seem to have failed, with the result that Taiwanese handset makers are now switching back to the OEM/ODM model. The most spectacular failure has been the attempt by the BenQ group (a spin-off of the Acer group) to accelerate its global branding strategy by acquiring the mobile handset business of Siemens and its intellectual property $^{14}$. That failure is all the more remarkable, as Stan Shih, the founder of Acer and one of the most influential strategic thinkers of Taiwan's IT industry, had placed high hopes that the acquisition of Siemens mobile handset business would allow BenQ to strengthen its own-brand business ${ }^{15}$.

\subsection{A focus on incremental innovation}

A second weakness of Taiwan's "global factory" innovation model is a disproportionate focus on incremental innovation. As specialized OEM/ODM suppliers, Taiwanese firms are heavily constrained in their capacity to develop new products and to shape technology road maps and standards. Taiwanese firms typically concentrate on incremental innovations within existing product architectures that are defined by global brand leaders who are charging hefty patent licensing fees. As a result, most Taiwanese IT firms have razor-thin profit margins. They are are caught in a "patent trap" - with rising production volumes, they must pay higher royalties, further undermining their profit margins High patent licensing fees also constrain diversification into new product markets with higher profit margins.

\subsection{Constraints to the development of home-made intellectual property}

While Taiwan's patent filings at the U.S. Patent and Trademark Office (USPTO) have grown rapidly, the quality of Taiwanese patents remains low (in terms of patent citation and "science linkages"). Hence, Taiwan may find it difficult to reduce the deficit in its technology balance of payments, as transfer payments for royalties and patent infringements are likely to rise. A related concern is that a weak patent portfolio might

\footnotetext{
${ }^{13}$ High Tech Computer (HTC) has successfully developed own-brand touch-screen smart phones, initially based on Microsoft's Windows Mobile operating system, but now also on Google's open-source Android platform.

${ }^{14}$ Less than one year after the acqusition, the German subsidiary, BenQ MobileGmbH \& Co OHG, was closed amid continuing huge losses at the subsidiary. BenQ's share of the Taiwan handset market now languishes around $8 \%$. To survive, BenQ is outsourcing handset production to Taiwanese contract manufacturers.

15 "BenQ spin-off to help realize own-brand success: Q\&A with Stan Shih", DigiTimes, 25 August 2006
} 
severely constrain the bargaining power of Taiwanese firms in negotiations about patent swapping with global technology leaders.

US patent data analysis does provide evidence of a rapid quantitative growth. Since 1999, Taiwan ranks second, ahead of Japan, in terms of the number of "all patents" it has filed at USPTO for every million of its population. And Taiwan ranks third since 2000 for the more valuable "utility patents" category ${ }^{16}$.

But Taiwan's high USPTO patent count is highly concentrated, both in terms products ("technology classes") and patent holders ("assignees"). The largest number of Taiwan's US patents is in semiconductor manufacturing, and these patents are dominated by two companies - TSMC, Taiwan's leading patent filer in 2005 and, with a declining share, $\mathrm{UMC}^{17}$. And Hon Hai, Taiwan's second largest patent filer in 2005, has pursued an aggressive strategy to file protective patents, especially for its connector technology. China has been the main focus - since $1995,61 \%$ of Hon Hai's patents were filed in China, against less than $18 \%$ in the $\mathrm{US}^{18}$.

As for the quality of Taiwanese patents, Lin (2005) documents persistent weaknesses, in terms of patent citation, science linkages, and technological capabilities ${ }^{19}$. Equally noteworthy is the persistent concentration of Taiwan's most influential patents TSMC has developed an overwhelming dominance, followed by Hon Hai, ITRI, Via, AUO, Macronix, UMC, Nanya and Siliconware.

Taiwan's IC design industry provides a telling example of the substantial constraints that the country is facing in its development of home-made intellectual property. Because of their role as specialized suppliers to global semiconductor and system companies, Taiwanese chip design firms have limited resources and incentives to close the technology gap relative to industry leaders. For instance, Taiwanese circuit design firms typically are not active at the leading-edge of process technology and IC complexity $^{20}$.

\footnotetext{
${ }^{16}$ USPTO classifies patents into utility patents and design patents. A utility patent protects any new invention or functional improvements on existing inventions (like going from LED technology to OLED), while a design patent protects the ornamental design, configuration, improved decorative appearance, or shape of an invention (like designer eyeglass frames, or the original Coca-Cola bottles). Note however the different definition used by China's Patent Office. China's utility model patents protect any new technical solution relating to the shape and/or structure of a product, which is fit for practical use. Utility patents offer the same protection (albeit for a shorter time span) as invention patents. But they are quicker and cheaper to obtain since a utility model receives only preliminary examination rather than the full substantive examination of an invention application.

${ }^{17}$ However, both TSMC and UMC are currently about half a year or a year behind Intel, the global leader, in terms of key technology parameters.

${ }^{18}$ Hon Hai has been expanding its USPTO patent portfolio, accounting for almost one third of Taiwan's growth in 2004 USPTO patent filings (Lin, 2005).

${ }^{19}$ Lin, Xin-Wu, 2005. An Analysis of Taiwan's Technological Innovation - on the Basis of USPTO Patent Data Analysis, slide presentation, Taiwan Institute of Economic Research, Taipei, 27 July. For instance, Taiwan's patents are less "original" than Korea's, i.e. they are less frequently cited within a technology class. Taiwan's patents have also less impact than Korea's, they are less frequently cited in other technology classes. As for science linkages, Taiwan's patents, even for semiconductors, are less frequently cited in scientific journals than Korea's patents. A particularly disturbing finding is that, since 2001, the citation index of Taiwan's utility patents has declined. Possible explanations are a decline in the number of frequently cited semiconductor patents and an increasing number of "low originality" patents.

${ }^{20}$ Teng, Joy, 2006. IC Design House Survey 2006: Taiwan, courtesy of Electronic Engineering Times Taiwan, www.eettaiwan.com.
} 
In addition, Taiwanese design houses have not been able to develop complete solution packages through in-house development of a broad set of complementary capabilities. For instance, in the important cellular chip-set market, only one Taiwanese design house (Mediatek) is offering a complete cellular chipset solution. All other Taiwanese companies that seek to compete in this market (like Sunplus and Airoha), have focused on specific building blocks and niche markets. In a market that is characterized by extremely rapid change and high unpredictability, such a focused approach is clearly a high-risk strategy.

\subsection{Hollowing-out through offshoring to China}

Offshore outsourcing is imposing severe hollowing-out pressures on Taiwan's IT industry, as more and more manufacturing, support services, and (most recently) R\&D are moving to lower-cost locations in China and Southeast Asia. This is reflected in a domestic value-added ratio that is much lower than for the US and Japan, and this ratio keeps declining ${ }^{21}$. To some degree, this hollowing-out effect, and the resultant job displacements, may have been reduced by the growth of Taiwanese exports to Asia (especially China) of increasingly sophisticated production equipment.

Taiwan's offshore outsourcing has been driven by the needs of the global brand marketers. The main objective was to retain the position as OEM/ODM suppliers, by neutralizing the rise in domestic labor costs and the appreciation of the NT-dollar. Most Taiwanese IT manufacturers have widely adopted a strategy of "receiving orders in Taiwan, shipping manufactured goods from China" (Chen, Liu and Lin (2005: 25). For the more successful of Taiwanese OEM/ODM suppliers, this has given rise to "a new cross-Strait division of labor along the lines of pilot run vs. mass production."

As offshoring is now being extended beyond manufacturing into product development, this is eroding competitive advantages that Taiwanese firms enjoyed while they were working only in Taiwan. Take chip design. As the production of computer, communications and consumer products has been moved mostly to China, Taiwan's IC design houses have been forced to follow suit to sustain close interaction with their customers. Moving product development to China may erode their competitive edge - a combination of flexibility, low cost and timely service that was the hallmark of Taiwan's high tech cluster.

In addition, once Taiwanese chip design companies have moved to China, they now are finding themselves exposed to intense competition from lower-cost China competitors. In fact, Taiwanese chip design houses are in danger of losing their most fundamental competitive advantage, i.e. access to a pool of highly trained and experienced lower-cost engineers and managers. Taiwan's great strength was that it could recruit knowledge workers from diverse sources, especially from its overseas high-skill diaspora. But this advantage is now being eroded, as China's IC design firms can now draw on Chinese returnees who have studied and worked in the US. Chinese design companies can also recruit former employees of Taiwanese companies who can train China's growing pool of local engineering graduates.

\footnotetext{
${ }^{21}$ Chen, Shin-Horng, Meng-chun Liu and Ku-Ho Lin, 2005. "Industrial Development Models and Economic Outputs: A Reflection on the 'High Tech, High Value-Added' Proposition", manuscript, Chung-Hua Institution for Economic Research, Taipei.
} 


\subsection{Weak branding power}

In contrast to global brand leaders from the US, Japan, Europe and Korea, Taiwanese IT firms lack strong global brands that they can leverage to penetrate China's rapidly growing market. This has provoked intense policy debates. Backed by substantial financial support, the government has launched a "Branding Taiwan" campaign, encouraging local firms to establish global brands.

Branding is of strategic importance - as a device to create differentiation, branding can enable Taiwanese firms to create customer loyalty and to reap premium prices. Yet, much of these efforts are focused on marketing. This neglects the systemic nature of Taiwan's weak branding power.

As specialized suppliers to global brand leaders, Taiwanese firms have rarely been directly exposed to the peculiar needs of final markets. In fact, the weak branding capabilities are a result of Taiwan's afore-mentioned structural weaknesses: unequal network integration, a focus on incremental innovation, constraints to the development of home-made intellectual property, as well as extensive internationalization.

All of these weaknesses are interrelated, and are not easy to change at short notice. And to change just one of them without changing the others might be well-nigh impossible. Hence, Taiwan's government and leading IT firms are searching for ways to develop an integrated innovation strategy that combines market-led innovation, intense public-private partnerships and public policy coordination.

\section{The new strategy - Low-cost and fast innovation through domestic and global innovation networks.}

\subsection{Objectives}

Taiwan's achievements in OEM/ODM contract manufacturing and in component manufacturing are impressive, covering a broad array of activities, including high-margin foundry services and IC design. However, a fundamental proposition underlying Taiwan's new innovation strategy is that this growth model is now facing serious limitations, as razor-thin profit margins in the OEM/ODM business provide limited funds for R\&D and risky innovations. There is a growing consensus in Taiwan that an exclusive focus on hardware manufacturing is no longer sufficient to guarantee sustainable growth. Taiwan's intention is to proceed from contract manufacturing and component production to systems integration and related services. A long-term objective is to strengthen Taiwan's software capabilities, especially for the design of complex system software. As discussed below, cloud computing is supposed to be an important catalyst for this transition to a new innovation model.

In short, Taiwan's new innovation strategy builds on its capacity for low-cost and fast manufacturing. But it seeks to complemented manufacturing excellence with knowledge-intensive support services and a capacity to provide "integrated solutions". In addition to "hard" technology capabilities, Taiwan's innovation policy thus seeks to foster simultaneously four sets of complementary "soft capabilities",22: 1) system integration: to design and integrate components and subsystems into a system; 2) operational services: to maintain, finance, renovate, and operate systems through the life

\footnotetext{
${ }^{22}$ The distinction between 'hard' and 'soft' innovation capabilities, is developed in Ernst, D., 2009, A New Geography of Knowledge in the Electronics Industry? Asia's Role in Global Innovation Networks. Policy Studies No. 54, August, East-West Center, Honolulu, HI, chapter 3.
} 
cycle; 3) business consulting: to understand a customer's business and to offer advice and solutions that address a customer's specific needs; and 4) finance: to provide a customer with help in purchasing new capital-intensive systems and in managing a customer's installed base of capital assets.

However, in order to compete with "integrated solutions" provided by American European and Japanese companies, Taiwanese firms need to focus on providing these solution packages at lower-cost, while shortening the cycle time required for bringing these services to the most promising markets. Hence, the focus now is on low-cost and fast innovation.

To implement this strategy, Taiwan's new innovation policy seeks to strengthen further the linkages and interactions among industry, academia, and public and private R\&D organizations. Given the small size of Taiwan's economy, these innovation networks need to cover both national and global innovation stakeholders. Chu quotes the following examples of such trilateral innovation networks: the Taiwan TFT-LCD Association; Next-Generation Lighting Alliance; New Nylon \& Polyester Textile R\&D Alliance; Fresh Food Logistic Service Industrial Alliance; RFID System; Advanced Optical Storage Research Alliance; and Environmentally Friendly Manufacturing Technology Alliance ${ }^{23}$. These network arrangements typically cover resource deployment, standardization, patent pooling, market development, multidisciplinary integration, and coordinated development.

As for international linkages, while Taiwan's focus for a long time was on integration with the innovation systems of the US, Japan and the EU, a recent development is that linkages with mainland China are rapidly expanding.

\subsection{Focus on China market}

Two basic assumptions are driving Taiwan's focus on the China market. First, Taiwan's IT industry is well placed to exploit China's rapid demand growth for IT products and services. Taiwan's foundries, IC design houses and ODM suppliers need to move fast to leverage their still substantial advantages relative to Chinese firms in product development and logistics. This requires a deliberate strategy to expand and deepen cross Taiwan Strait cooperation and integration with China's innovation system through, for instance joint standardization projects.

Second, Taiwan's government is convinced that China is gradually becoming a regional technology leader. As a result, "Taiwan has to come to terms with this reality by realigning its industrial science and technology development and the relevant policy addressing the cross-strait issues." 24 This has led to new initiatives for cross-strait cooperation in industrial standards, for broader bilateral economic cooperation, especially through the Economic Cooperation Framework Agreement (ECFA) ${ }^{25}$, and through the deregulation of Chinese investment in Taiwan.

\footnotetext{
${ }^{23} \mathrm{Chu}$, Hsin-Sen, 2007, “The Taiwanese Model: Cooperation and Growth", in Wessner, C.W., editor, Innovation Policies for the $21^{\text {st }}$ Century. A Report of a Symposium, The National Academies Press, Washington, D.C. : p.119

${ }^{24}$ Chen, Shin-Horng, 2010, Country Report Taiwan, prepared for European Commission, International Center for Economic Growth, Contract \# 150970-2008 F1SC-HU, October: page 66.

${ }^{25}$ ECFA is a special free trade agreement between Taiwan and China, which was concluded in September 2010.
} 
Of particular interest are recent developments in cross-strait cooperation in industrial standards. For instance, both sides have reached agreements to work together on the fields of TD-SCDMA, LCD, LED and solar cells. Much of this joint standards development is still limited to production and applications and has not yet been extended to system architecture and platforms. This reflects the continuous weakness of Taiwanese firms in architectural or radical innovations.

However, in the medium-term this is likely to change. If that happens, this will enable Taiwanese IT firms to participate as equal players at an early stage in the formation of the Chinese industrial standards and/or dominant architecture design. If that would happen, the US IT industry might well experience a loss of its bargaining power in terms of its access to critical components and systems.

\subsection{Implications for linkages with the US}

As Taiwan's IT industry is now increasingly integrated with China's economy and its innovation system, this raises important questions: Will the link to China become more important than the link to the US? And if so, how will this affect America's access to the semiconductor global value chain?

Historically, Taiwan's IT industry has greatly benefited from its deep integration with America's innovation system, especially Silicon Valley. Equally important, is that America's IT and semiconductor industry are heavily dependent on Taiwan. US IT companies remain the most important buyers of Taiwanese ODM and OEM services. And Taiwan's silicon foundries are a critical supplier of process technology as well as manufacturing and design services to US fabless design companies.

In addition, Taiwan seeks to induce leading US IT companies to establish R\&D centers in Taiwan. The government believes that such R\&D centers can help to accelerate Taiwan's "upgrading through innovation" strategy ${ }^{26}$.

In the IT industry, Taiwan has been able to exploit its first-tier supplier advantage as a means of attracting major US IT companies to set up their offshore R\&D facilities on the island. Those US labs have tended to conduct certain types of R\&D in Taiwan, ranging from medium-term product/process applied development, short-term innovation, and prototype development to significant adaptation and improvement to existing technologies.

Hence, much is at stake for both the US and Taiwan. However, Taiwan faces a fundamental dilemma. China has become not only the most important production site for Taiwan's IT companies, but also a major growth market. In addition, continuous penetration of the China market requires that Taiwanese firms now also redeploy new product development and some research to China. This implies that Taiwanese firms now need to provide critical inputs (through training, technology transfer and joint product development) to Chinese firms that will enable them to accelerate their catching-up strategies.

\footnotetext{
${ }^{26}$ Using data collected by the Investment Commission of the Ministry of Economic Affairs (MOEA), Liu and Chen find that R\&D intensity (R\&D/sales) for foreign-owned subsidiaries (most of them from the US) in Taiwan's manufacturing sector increased from $1.52 \%$ in 2002 to $1.94 \%$ in 2003; which perhaps indicates that Taiwan's mandate has significantly improved in terms of MNCs' regional or GINs. (Liu, Meng-Chun and Shin-Horng Chen, 2006. "Cross-Border R\&D Networks and International R\&D: A Quantitative Study of Taiwanese Firms", manuscript, Chung-Hua Institution for Economic Research, April).
} 
In short, will Taiwan be able to sustain simultaneously its deep integration with China and the US? Can Taiwan strike a balance between cooperation with China and cooperation with the US? Or will the sheer weight of China force Taiwanese firms to give priority to their links with China?

It is too early for a conclusive answer to these questions. So far, however, Taiwan's economic diplomacy related to the IT industry remains closely aligned with the US position ${ }^{27}$.

\section{Role of Government - Key policies and initiatives in the IT industry 4.1. Financial incentives}

To promote its new strategy of "low-cost and fast innovation", Taiwan provides aggressive tax incentives as part of its Statute for Industrial Innovation. Since 2010, the business income tax has been lowered from 25\% to 17\% (China 25\%, Korea 22\%, and Singapore 17\%), but at the same time the business income tax credits have been reduced from $35 \%$ to $15 \%$ for the R\&D expenditures.

An important characteristic of the new polices is that SMEs are offered subsidies for the hiring of additional personnel with innovation abilities. These subsidies, which will be NT $\$ 10,000$ (approximately $\$ 3436.52$ ) per employee per month for a period of up to one year, aimed at lowering operating costs for SMEs and strengthen their manpower.

\subsection{Public-private partnerships}

Taiwan's innovation policy seeks to strengthen the lead role of the private sector by generating new public-private partnerships and by coordinating their interactions. According to ITRI's $\mathrm{Chu}^{28}$,

"the government does provide private companies with funding to 'encourage' them to embrace research projects chosen as the result of an evaluation process conducted by a committee. This 'encouragement' usually takes the form of granting a company 25 percent of the research budget; the company is to put up 50 percent of the financing itself, with the remaining 25 percent covered by a government or bank loan.

Similarly, when ITRI transfers technology it has developed to a company so that it can undertake product development, the government provides around 20 to 25 percent of the research budget in recognition of the risk involved; in these cases, a committee at the Ministry of Economic Affairs reviews the projects and decides where to place resources."

To foster industrial upgrading through "low-cost and fast innovation", Taiwan's government uses three major initiatives:

- the Technology Development Programs (TDPs), administered by the Department of Industrial technology (DoIT);

\footnotetext{
${ }^{27}$ For instance, during the November 2011 Asia-Pacific Economic Cooperation (APEC) meeting in Honolulu, Taiwan has supported US proposals to extend the Information Technology Agreement (ITA) and to establish an Environmental Goods and Services (EGS) program.

${ }^{28}$ Chu, Hsin-Sen, 2007, “The Taiwanese Model: Cooperation and Growth”, in Wessner, C.W., editor, Innovation Policies for the $21^{\text {st }}$ Century. A Report of a Symposium, The National Academies Press, Washington, D.C.: p.120.
} 
- a redefinition of the mission of the Industrial Technology Research Institute (ITRI);

- a redefinition of the role of Science Parks, especially that of the Hsinchu Science Park

\subsection{Technology Development Programs (TDPs)}

The DoIT's Technology Development Programs seeks to integrate the R\&D resources and knowledge of research institutes, academia, and industry. An important objective is to jointly develop advanced key cross-domain technologies to enhance the R\&D capability of the industry and consolidate Taiwan's strength in applied technologies. Of particular interest are Taiwan's Small Business Innovation Research Program (SBIR), modeled after the US SBIR, and the Multinational Innovative $R \& D$ Centers in Taiwan Program.

The SBIR Program has resulted in a total of 609 granted projects amounting to over NTD 640 million (approximately \$21.5625 million) in government sponsorship. According to the DoIT, this has resulted in industry re-investment in R\&D amounting to approximately NTD 1.13 billion (approximately $\$ 38.0712$ million) and the direct involvement of over 3,000 people in $R \& D$ projects.

And the Program on Multinational Innovative R\&D Centers seeks to foster collaboration among MNCs and local firms so that Taiwan can establish itself as a regional R\&D center within the Asia Pacific region.

\subsection{Redefining the role of Science Parks}

Established in 1980, the Hsinchu Science Park has been a major player in the commercialization of research in Taiwan. This government-planned cluster was based on the Silicon Valley model, with easy entry for small and medium size manufacturing companies; easy access to venture capital; public funds and resources for public-private joint research and automation of production; and the focus on higher education for the workforce were all part of a strategy of letting firms specialize and be quick to go from design to production.

Today the science park is among the world leaders in technology research, development and production within the areas of integrated circuits, computers and peripherals, telecommunications, optoelectronics, precision machinery, and biotechnology. The science park has become the world's leading cluster for semiconductor manufacturing.

However, an important constraint is a chronic water shortage that reflects the park's heavy concentration on wafer fabrication that is among the heaviest consumers of scarce water. Industry statistics indicate that creating an integrated circuit on a $300 \mathrm{~mm}$ wafer requires approximately 2,200 gallons of water in total, of which 1,500 gallons is ultrapure water. Water-related costs result from obtaining water, producing deionized and ultrapure water in large-scale volumes, and treatment and disposal of wastewater ${ }^{29}$.

\footnotetext{
${ }^{29}$ Industry participants estimate the annual spending of the global semiconductor industry on water and wastewater systems and services to be around $\$ 1$ billion, with half of that figure relating to capital equipment purchases. Global Water Intelligence, 2011, "Pure water, semiconductors and the recession" http://www.globalwaterintel.com/archive/10/10/market-insight/pure-water-semiconductors-and-therecession.html
} 
In response, Taiwan's government now seeks to promote investment in more water-efficient equipment and processes which, along with recycling and reclamation, could reduce reduce cost and environmental impact. There are also attempts to reduce wafer fabrication capacity in Hsinchu Science Park by outsourcing new fabs and related component manufacturing to other related science parks in Central and Southern Taiwan, and their own satellite industrial clusters. In the medium-term, the government's strategy seeks to promote investment in new less water-consuming and more environmentally friendly sectors, such as optoelectronics, precision machinery and especially biotechnology and medical devices.

\subsection{Redefining the role of the Industrial Technology Research Institute (ITRI)}

The Industrial Technology Research Institute (ITRI) is a national research organization that serves to strengthen the technological competitiveness of Taiwan. With over 6,000 employees and an operating budget of about US\$510 million (half from the MOEA and half from private sources), ITRI is the largest research institute in Taiwan. The core of ITRI's operations consist of basic research and development conducted in various applied technologies. Most of the research staff at ITRI have graduate degrees. Research projects are conducted with close cooperation and partial funding from small and medium-sized companies. The results of the research are transferred to these sponsors for further development and eventual manufacture for industry. In the IT industry, and especially in semiconductors, ITRI has played a fundamental role as an enabler and coordinator by facilitating technology transfer, investing in training of the national work force, and supporting spin-offs. Some ITRI research units have spun off into successful companies of their own, such as UMC and Winbond Electronics.

External collaboration is a key element of ITRI's approach to research and innovation. For instance, the Institute collaborates with national industry champion TSMC when large scale facilities are needed for large pilots. In addition to its own research units, ITRI rents out and provides logistical support to fledgling industrial enterprises (including its own spin-offs) at its Incubation Center and Open Laboratory program.

ITRI has an international division to seek out partners for the benefit of Taiwanese industries. ITRI has signed research alliances with leading US companies such as IBM, Microsoft, SRI International, and many leading US universities like UC Berkeley (on nanotechnology, semiconductors, and energy-related research), MIT (robotics), Carnegie Mellon University (communications technologies),Stanford University, UCLA, and the Georgia Institute of Technology.

To foster technology sourcing and knowledge exchange, and to collect strategic market intelligence, ITRI also maintains overseas offices in San Jose, Tokyo, Berlin, and Moscow. ITRI has close links with Germany's Fraunhofer Institutes, Belgium's IMEC at Louvain, the Netherlands' Organization for Applied Scientific Research, Japan's National Institute of Advanced Science and Technology, Russia's Joffe Physico-technical Institute, the National Research Council of Canada (NRC), and Australia's Commonwealth Scientific and Industrial Research Organization. Of particular interest is 
the recent proliferation of cooperation agreements with leading research institutions in mainland China.

An important recent development is that ITRI is now moving away from a catchup paradigm and is focusing on innovation by providing incentives for entrepreneurs to engage in ventures that produce low-cost innovations with high commercial potential. A particular focus is the development of Taiwan's software capabilities. An example is ITRI's Cloud Computing Center for Mobile Application, established in September $2009^{30}$. Its mission is to use Internet-based, on-demand computing ("cloud computing") as a catalyst for strengthening Taiwan's software capabilities, building on Taiwan's strengths in lower-cost hardware like memory, chipsets, server, storage network equipment.

A particular focus is on developing new applications especially for SMEs. ITRICCCMA' primary role is to provide access to relevant hardware and software technologies in order to enable the design of low-cost containerized data centers. An important objective is to help Taiwanese SMEs in the acquisition, absorption and customization of software packages provided mainly by major U.S. vendors.

While earlier attempts to develop Taiwan's software industry have not produced tangible results, today there are better chances to succeed. The main reason is that the media hype about "the cloud" has captured the attention of Taiwanese IT companies. On the one hand, these companies fear that Internet-based, on-demand computing that delivers software, storage and other services via the Web from vast data centers will erode the traditional PC-based computing model, in which software is stored in individual machines. That fear explains why Taiwanese firms now pay attention to the government's cloud computing initiatives, and why these firms are now willing to participate as active players in the Taiwan Cloud Computing Consortium.

At the same time, Taiwanese IT companies recognize that a paradigm shift to Internet-based, on-demand computing could provide new opportunities to leverage existing strengths in fast and low-cost manufacturing.

\section{Conclusions}

To conclude, Taiwan's new innovation strategy reflects fundamental transformations in the global knowledge economy. "Ubiquitous globalization" now reaches beyond markets for goods and finance into markets for business services, technology, intellectual property rights, and knowledge workers ${ }^{31}$. The result is an increase in the organizational and geographical mobility of knowledge. However, the new geography of knowledge is not a flatter world where technical change and

\footnotetext{
${ }^{30}$ Author's interview with Dr. Tzi-Cker Chiueh, General Director, ITRI-CCCMA, April 25, 2011. As is typical for Taiwan's leading innovation actors, Dr. Chiueh's education and employment history shows strong links with the US. He received his B.S. in EE from National Taiwan University, M.S. in CS from Stanford University, and Ph.D. in CS from University of California at Berkeley in 1984, 1988, and 1992, respectively. Dr. Chiueh was a Professor in the Computer Science Department of Stony Brook University, directed the Core Research group at Symantec Research Labs, was Principal Scientist for U.S. Rether Networks, and strategic advisor for the United States Defense Advanced Research Projects Agency (DARPA).

${ }^{31}$ Ernst, D., 2011, Indigenous Innovation and Globalization: The Challenge for China's Standardization Strategy, UC Institute on Global Conflict and Cooperation; La Jolla, CA and East-West Center, Honolulu, HI., 123 pages http://www.EastWestCenter.org/pubs/3904, chapter 3,
} 
liberalization rapidly spread the benefits of globalization. Instead, a handful of new - yet very diverse and intensely competing - manufacturing and R\&D

hubs are emerging in Asia.

For Taiwan to survive the intensifying technology-based global competition, it is necessary to move beyond its traditional "global factory" innovation model. But "technology leadership" strategies that focus on radical innovations to compete head-on with global technology leaders are beyond the reach of most Taiwanese companies in the IT industry. Even TSMC, the world's leading IC foundry has had to stretch its resources to the limits. Its success was built on pursuing a "technology leadership" strategy in IC process technology. This enabled TSMC to charge premium prices. But sustaining process technology leadership comes at an extremely high cost and risk ${ }^{32}$. And staying at the frontier of process technology requires dense interaction with top scientists and engineers who work at the frontier of basic and applied research in a broad range of disciplines.

As a result, TSMC had to invest in a broad range of global innovation networks with leading R\&D partners. This includes leading labs in Berkeley, MIT and Stanford and at the Inter-University Microelectronics Center (IMEC) in Louvain/Belgium, as well as close partnerships with tool and IP vendors and key customers. The cost of establishing and sustaining such networks no doubt exceeds by far the resources of most Taiwanese IT companies.

Nevertheless, the future of Taiwan's IT industry critically depends on quick access to radical innovations, especially in generic technologies. For instance, Taiwanese firms need core component technologies and insider information on interface standards, in order to compete in the access network industry. The same is true for in system-onchip (SOC) design for wireless and optoelectronics systems and for embedded processors. And quick application of nano-technology research is critical for the upgrading of Taiwan's semiconductor and optoelectronics industries.

To move ahead in these areas obviously requires concerted industry-level upgrading efforts by the government and industry. Such efforts are needed to reduce the very substantial barriers that individual firms face when they try to move to technology leadership strategies. Taiwan has significant policy initiatives in each of the above areas ${ }^{33}$.

The risk of failure however remains high. This implies that an exclusive focus on technology leadership strategies is unlikely to support a broad-based upgrading through innovation strategy. This explains why Taiwan's new innovation strategy emphasizes "low-cost and fast innovation" through domestic and global innovation networks.

The capability requirements of such a strategy are demanding, but they are within reach of Taiwanese companies that have been successful OEM/ODM suppliers. Of critical importance is a capacity to develop products and services that are less overengineered and expensive than those of global market leaders, and that address "effective customer needs" 34 that incumbent global market leaders have neglected.

\footnotetext{
${ }^{32}$ Establishing a state-of-the-art factory ("fab") that is capable of producing chip from 12-inch wafers with 90-nanometer process technology requires an investment of up to $\$ 4.5$ billion.

${ }^{33}$ On SOC design, the government has initiated a "National SOC Research Program". On Nanotechnology R\&D, the government has committed substantial funds, while ITRI and the National Science Council have signed an agreement to conduct joint research with the National Research Council of Canada. And Sha et al (2006) describe ITRI's role in the industry-level upgrading of Taiwan's access network industry.

34 "Effective customer needs" are those that customers are willing to pay for.
} 
And barriers to implement that new architecture are limited. In fact, Taiwanese firms do not need to develop the necessary components, nor do they have to change them. Taiwan's deep integration into global production and innovation networks enable Taiwanese firms to buy the relevant component technology from specialized suppliers. Taiwanese firms also might engage in collaborative development of some of these components.

A few leading Taiwanese IT firms are now making serious efforts to catch up in the mastery of these most critical innovative capabilities. For instance, HTC, Taiwan's leading own-brand handset vendor, has developed highly successful commercial smart handsets and it uses an open-source platform for its partners to collaborate. And Asus, among other interesting projects, has used a loosely coupled global product development network to bring to market at record speed the first commercially viable ultra-low cost laptop.

But Taiwan still has a long way to go. The challenge for its innovation policy is to foster "integrated solutions" capabilities on an industry-wide level so that individual firms can access these capabilities without encountering the extremely high cost burden of developing them in-house. 